\title{
ANALISIS CLUSTER UNMET NEED KELUARGA BERENCANA DI INDONESIA
}

Sih Kawuri Sejati
Fakultas Ekonomi dan Bisnis Universitas Indonesia
Badan Pusat Statistik Kabupaten Minahasa, Sulawesi Utara
wuri.sejati@gmail.com

Diterima: Februari 2020; Disetujui: April 2020

\begin{abstract}
Control of population through Family Planning and Family Development is one of the strategic issues listed in the 2015-2019 RPJMN. One of the problems faced in family planning services is the high number of unmet need in Indonesia. Apart from the high national unmet need, there is still a high gap for unmet need in the provinces in Indonesia. The unmet need gap between provinces in Indonesia has caused there is no solution that can solve this problem. This study aims to group provinces in Indonesia based on the level of unmet need and the factors that influence it. Using secondary data from BPS and cluster analysis, the result of four provincial groups were obtained. Nearby provinces tend to cluster in the same cluster.
\end{abstract}

Keyword: cluster, family planning, unmet need.

Abstraksi. Pengendalian jumlah penduduk melalui Keluarga Berencana dan Pembangunan Keluarga merupakan salah satu isu strategis yang tercantum dalam RPJMN 2015-2019. Salah satu permasalahan yang dihadapi dalam pelayanan KB adalah masih tingginya angka unmet need di Indonesia. Selain masih tingginya unmet need secara nasional, masih terdapat kesenjangan yang tinggi untuk unmet need pada provinsiprovinsi di Indonesia. Masih adanya kesenjangan unmet need antar provinsi di Indonesia menyebabkan belum adanya solusi yang bisa memecahkan permasalahan tersebut. Penelitian ini bertujuan mengelompokkan provinsi-provinsi di Indonesia berdasarkan tingkat unmet need dan faktor-faktor yang memengaruhinya. Dengan menggunakan data sekunder dari publikasi BPS dan analisis cluster, didapatkan hasil empat kelompok provinsi. Provinsi-provinsi yang berdekatan cenderung mengelompok dalam satu cluster yang sama.

Kata kunci: cluster, KB, unmet need.

\section{PENDAHULUAN}

Pengendalian jumlah penduduk melalui

Keluarga Berencana (KB) dan Pembangunan Keluarga merupakan salah satu isu strategis yang tercantum dalam RPJMN 2015-2019. Menurut UndangUndang nomor 52 tahun 2009 tentang Perkembangan Kependudukan dan Pembangunan Keluarga, perkembangan kependudukan terdiri dari aspek kuantitas, kualitas, dan mobilitas penduduk, serta perencanaan dan wawasan kependudukan. Sementara itu, menurut Undang-Undang nomor 17 tahun 2007 tentang RPJPN 2005-
2025, kemajuan suatu bangsa dapat diukur berdasarkan indikator kependudukan. Bangsa yang sudah maju ditandai dengan laju pertumbuhan penduduk yang lebih kecil, harapan hidup yang meningkat, serta kualitas pelayanan sosial yang baik. Oleh karena itu, untuk mewujudkan hal-hal tersebut, diperlukan kualitas sumber daya manusia yang tinggi. Untuk dapat meningkatkan kualitas SDM, maka harus diwujudkan jumlah penduduk seimbang, yaitu dengan adanya pengendalian jumlah penduduk melalui program KB (Bappenas, 2015). 
Upaya untuk meningkatkan pemakaian $\mathrm{KB}$ harus diimbangi dengan peningkatan akses dan kualitas pelayanan secara merata. Salah satu permasalahan yang dihadapi dalam pelayanan KB adalah masih tingginya kebutuhan $\mathrm{KB}$ yang tidak terpenuhi (unmet need). Berdasarkan hasil SDKI 2017, angka unmet need KB di Indonesia adalah sebesar 10,6 persen, terdiri dari 4,1 persen untuk menjarangkan kelahiran, dan 6,5 persen untuk membatasi kelahiran.

Tingginya angkat unmet need dapat berdampak pada hal-hal seperti kehamilan yang tidak diinginkan yang dapat menimbulkan risiko bagi wanita, keluarga, dan lingkungannya. Salah satu konsekuensi dari kehamilan yang tidak diinginkan adalah aborsi. Diperkirakan 18 juta aborsi illegal dilakukan setiap tahun pada negaranegara berkembang, yang menyumbangkan tingginya angka kematian maternal. Selanjutnya, kelahiran yang tidak diinginkan menimbulkan risiko bagi kesehatan dan kesejahteraan anak serta berkontribusi pada tingginya laju pertumbuhan penduduk (Ashford, 2003).

Beberapa penelitian sebelumnya telah menemukan faktor-faktor yang mempengaruhi unmet need $\mathrm{KB}$ pada wanita usia subur, antara lain usia kawin pertama (Ali \& Okud, 2013; Clark et al., 2017; Hailemariam \& Haddis, 2011; Imasiku et al., 2014), pendidikan (Anggraeni, 2016; Hailemariam \& Haddis, 2011; Imasiku et al., 2014; Jidar, 2018; Nzokirishaka \& Itua, 2018; Paramita \& Baroya, 2017; Wulifan et al., 2016), status bekerja (Anggraeni, 2016; Hailemariam \& Haddis, 2011; Paramita \& Baroya, 2017), dan jumlah anak lahir hidup (Hailemariam \& Haddis, 2011; Imasiku et al., 2014; Jidar, 2018; Novianto et al., 2017; Nzokirishaka \& Itua, 2018; Withers et al., 2010; Wulifan et al., 2016).
Di Indonesia, masih terjadi kesenjangan unmet need yang cukup tinggi antar provinsi. Berdasarkan hasil SDKI 2017, unmet need provinsi-provinsi di Indonesia berada pada rentang 5,6 sampai dengan 23,6 persen.

Laporan SDKI 2017 menyatakan bahwa masih terdapat 10,6 persen wanita kawin berusia 15-49 tahun dengan kebutuhan KB yang belum terpenuhi, dimana 4,1 persen diantaranya untuk menjarangkan kelahiran dan 6,4 persen sisanya bertujuan untuk membatasi kelahiran. Kejadian unmet need KB tersebut dapat dikarenakan adanya kekhawatiran pada wanita akan kemungkinan timbulnya masalah kesehatan akibat efek samping dari alat/cara KB yang digunakan. Alasan lain yang mendasari wanita tidak menggunakan alat/cara KB antara lain penolakan baik dari wanita tersebut maupun pasangannya, dan larangan agama.

Pada gambar 1 terlihat bahwa sebaran unmet need $\mathrm{KB}$ di Indonesia masih mengalami kesenjangan, dimana unmet need terendah sebesar 5,6 persen di Provinsi Bangka Belitung dan unmet need tertinggi sebesar 23,6 persen di Provinsi Papua Barat. Masih terdapat 20 provinsi dengan persentase unmet need $\mathrm{KB}$ di atas persentase nasional, yaitu 10,6 persen.

Salah satu lembaga pemerintah yang bertugas untuk menurunkan tingkat unmet need $\mathrm{KB}$ di Indonesia adalah BKKBN. BKKBN memiliki kantor perwakilan di masing-masing provinsi yang bersifat vertikal sehingga kebijakan yang diambil adalah merupakan kebijakan yang bersifat nasional. Oleh karena itu, masih adanya kesenjangan tingkat unmet need $\mathrm{KB}$ pada provinsi-provinsi di Indonesia memerlukan kebijakan yang berbeda-beda antar provinsi untuk menemukan solusinya. 


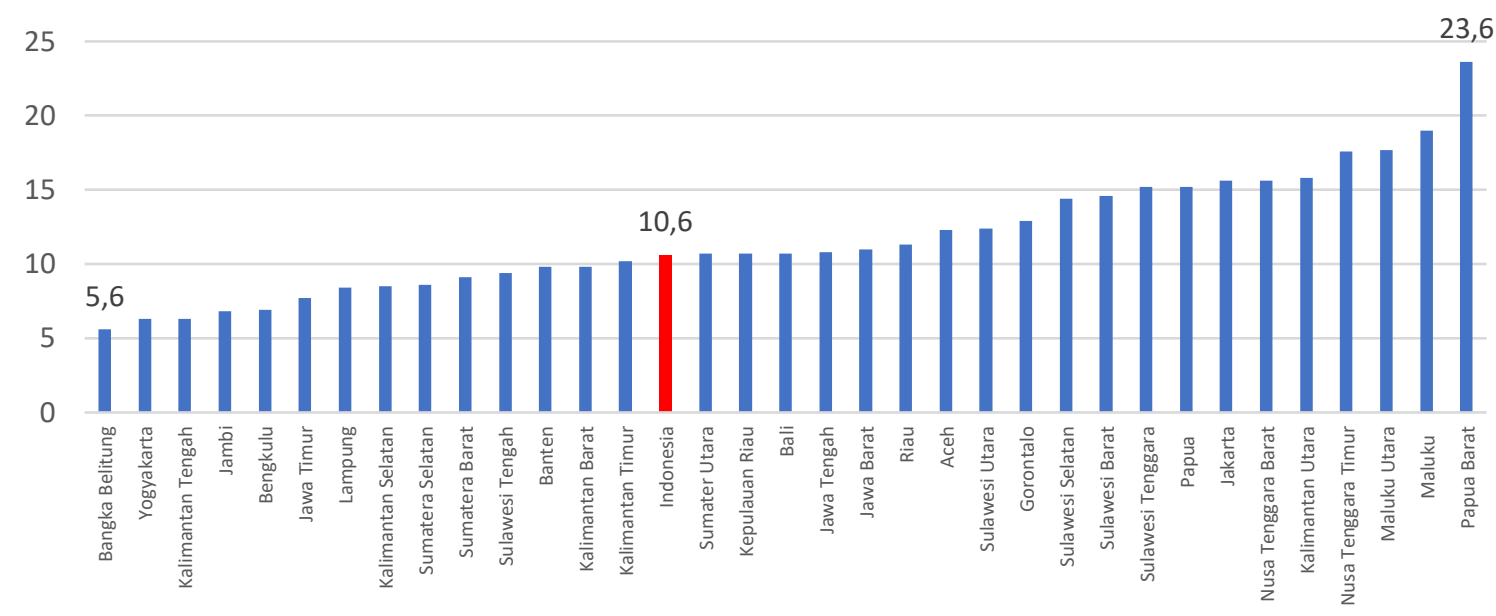

Gambar 1.

Unmet Need KB menurut Provinsi, 2017

Sumber : SDKI 2017, diolah

Selama ini penelitian mengenai unmet need terbatas pada faktor-faktor yang memengaruhinya saja dan dianalisis pada tingkat individu. Beberapa penelitian membandingkan perbedaan unmet need $\mathrm{KB}$ antar wilayah perdesaan/perkotaan dan kabupaten/kota (Nindya, 2011; Putro \& Listyaningsih, 2017), namun belum ada penelitian yang membandingkan perbedaan tingkat unmet need antar provinsi. Oleh karena itu, penelitian ini akan membandingkan unmet need antar provinsi beserta faktor-faktor yang memengaruhinya dengan menggunakan data tingkat provinsi. Penelitian ini bertujuan untuk mengelompokkan provinsi-provinsi di Indonesia berdasarkan karakteristik unmet need dan faktor-faktor yang mempengaruhinya. Pengelompokan unmet need berdasarkan faktor-faktor yang memengaruhinya dapat dijadikan sebagai dasar penentuan kebijakan pemerintah dalam upaya penurunan tingkat unmet need.

\section{METODE PENELITIAN}

Data yang digunakan dalam penelitian ini adalah data sekunder yang dipublikasikan oleh Badan Pusat Statistik
(BPS). Unit analisis yang digunakan adalah 34 provinsi di Indonesia pada tahun 2017.

Variabel yang digunakan dalam penelitian ini antara lain persentase unmet need KB, Tingkat Partisipasi Angkatan Kerja (TPAK) wanita, median usia kawin pertama, rata-rata jumlah anak masih hidup, dan rata-rata lama sekolah wanita.

Metode analisis yang digunakan dalam penelitian ini adalah analisis cluster. Analisis cluster merupakan suatu metode untuk mengelompokkan individu-individu ke dalam beberapa cluster (kelompok) dimana setiap unit pengamatan dalam satu cluster akan memiliki karakteristik yang relatif sama, sedangkan individu pada cluster yang berbeda memiliki karakteristik yang berbeda.

Analisis cluster dibagi menjadi dua metode, yaitu metode berhirarki (hierarchical clustering method) dan metode tidak berhirarki (nonhierarchical clustering method). Metode berhirarki digunakan apabila banyaknya cluster yang akan dibentuk tidak diketahui, sedangkan metode tidak berhirarki digunakan apabila banyaknya cluster yang akan dibentuk sudah diketahui sebelumnya. 
Pada penelitian ini, banyaknya cluster yang akan dibentuk sudah ditentukan lebih dahulu, sehingga analisis cluster yang akan digunakan adalah analisis cluster tidak berhirarki (K-means Clustering). Dalam metode ini diasumsikan bahwa analisis terdiri dari $n$ individu dan $p$ pengukuran.

Penentuan jumlah cluster terbaik dilakukan dengan menggunakan Metode Elbow. Metode Elbow dilakukan dnegan running k-means cluster dengan berbagai nilai cluster, kemudian menghitung nilai Sum Square Error (SSE) masing-masing cluster tersebut. Jumlah cluster terbaik adalah pada saat jumlah SSE berkurang paling signifikan pada setiap penambahan jumlah cluster.

\section{HASIL DAN PEMBAHASAN}

Tingkat Partisipasi Angkatan Kerja (TPAK) perempuan merupakan perbandingan perempuan yang termasuk dalam Angkatan kerja (bekerja dan pengangguran) dengan jumlah perempuan usia kerja (15 tahun ke atas). Sebaran TPAK perempuan dapat dilihat pada gambar 2. TPAK perempuan tertinggi berada pada Provinsi Bali sebesar 67,7 persen dan terendah pada Sulawesi Utara sebesar 41,7 persen. TPAK perempuan yang lebih tinggi akan meningkatkan otonomi perempuan sehingga perempuan lebih berdaya dalam memilih alat/cara $\mathrm{KB}$ yang akan digunakan dan pada akhirnya akan mengurangi unmet need $\mathrm{KB}$.

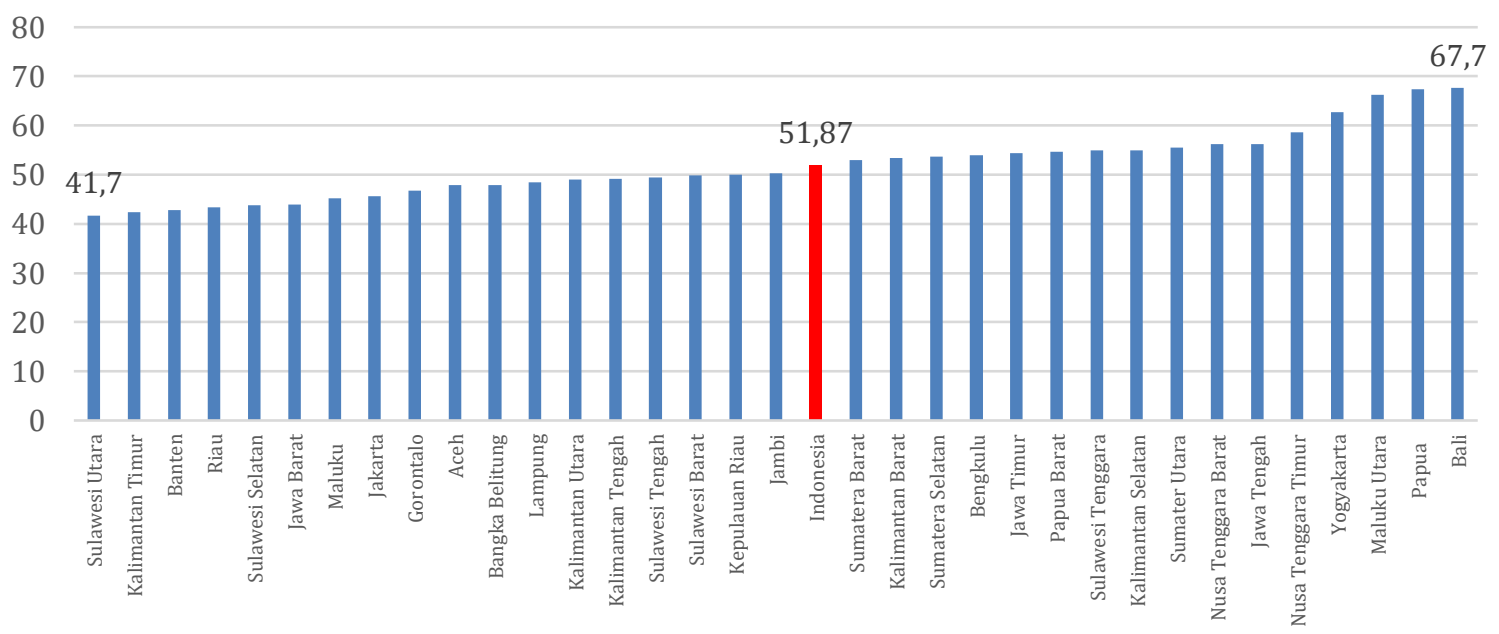

Gambar 2.

Tingkat Partisipasi Angkatan Kerja (TPAK) Perempuan menurut Provinsi, 2017 Sumber : BPS, 2017

Median usia kawin pertama di pertama yang rendah menyebabkan Indonesia pada tahun 2017 adalah 21,8 tahun. Pada gambar 3 terlihat bahwa median usia kawin pertama terendah adalah pada Provinsi Kalimantan Tengah yaitu 20,8 tahun, dan tertinggi pada Provinsi Jakarta, yaitu 23,9 tahun. Usia kawin perempuan akan memiliki jumlah anak sesuai dengan jumlah anak ideal pada usia dini yang pada akhirnya akan meningkatkan pemakaian KB pada daerah tersebut dan pada akhirnya akan mengurangi unmet need KB. 


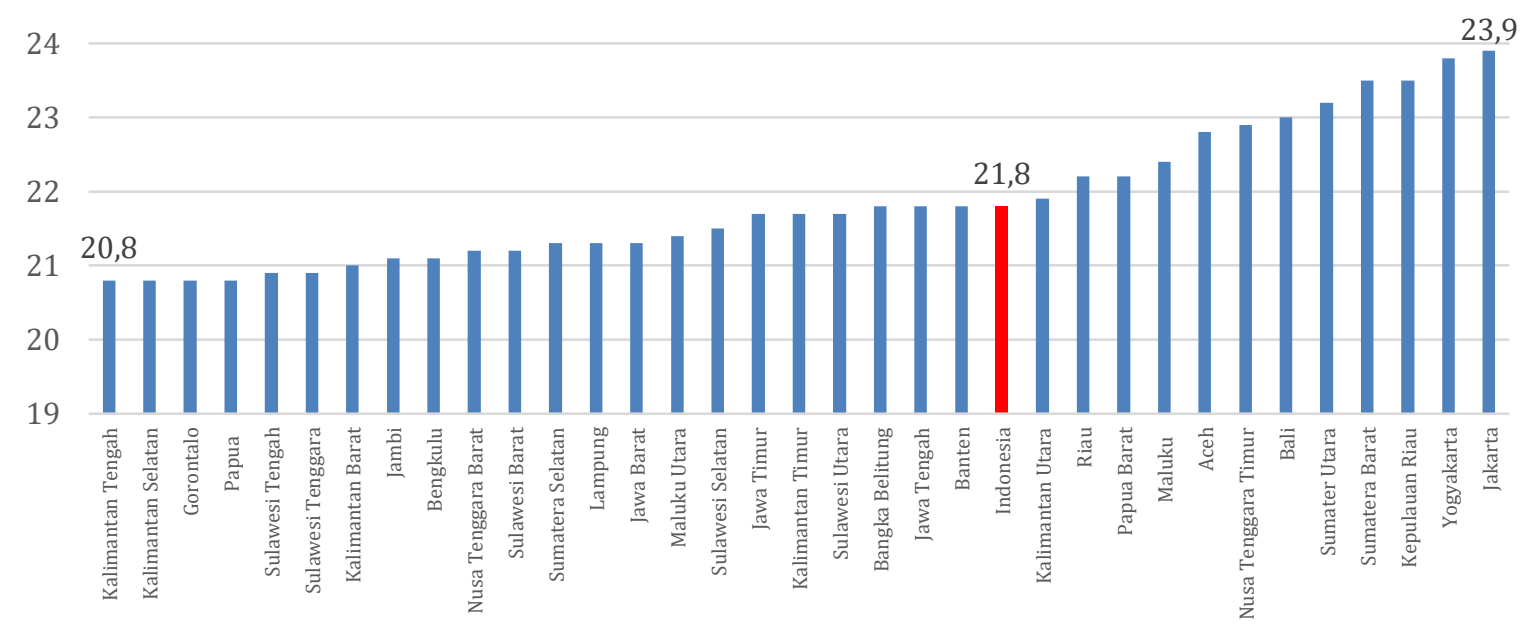

Gambar 3. Median Usia Kawin Pertama Perempuan, 2017

Sumber : BPS, 2017

Menurut Laporan SDKI 2017, rata-rata anak masih hidup per perempuan di Indonesia adalah sebanyak 1,63. Rata-rata anak masih hidup terendah berada pada Provinsi Yogyakarta sebanyak 1,25 dan tertinggi di Papua sebanyak 1,96. kontrasepsi untuk membatasi kelahiran.

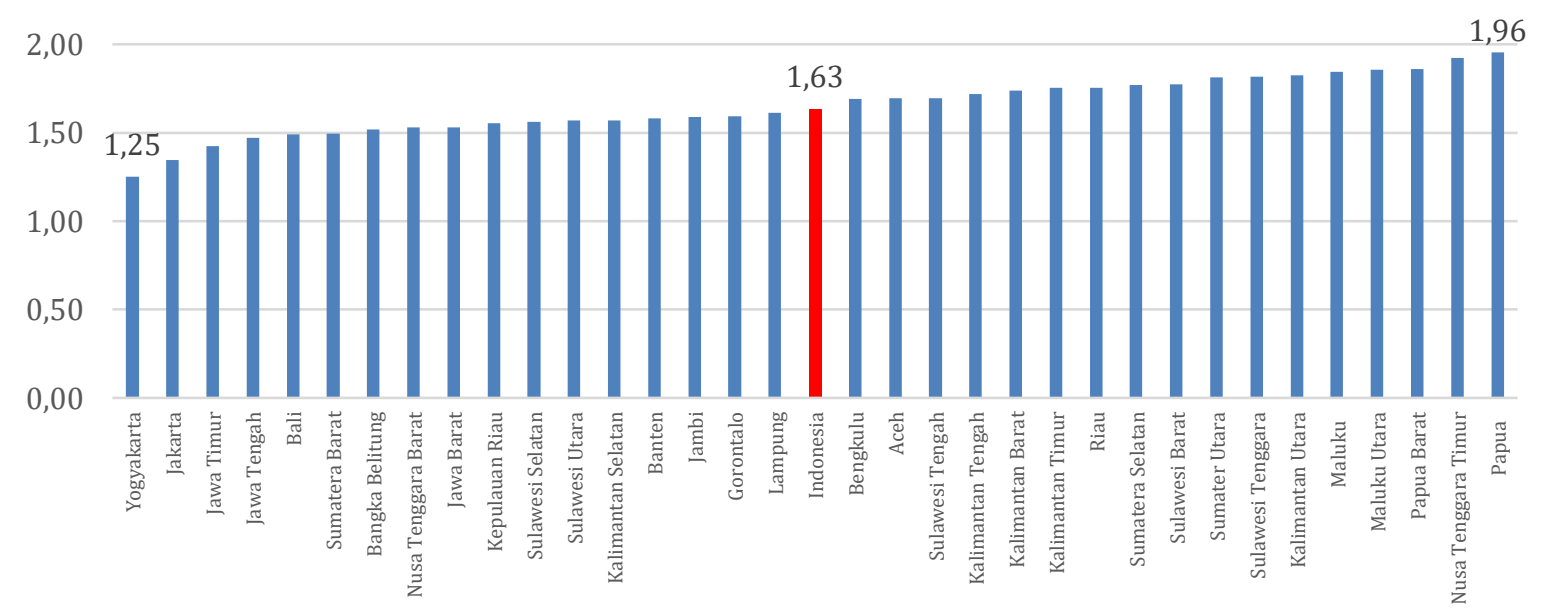

Gambar 4. Rata-rata Jumlah Anak Masih Hidup menurut Provinsi, 2017 Sumber : SDKI 2017, diolah

Rata-rata lama sekolah wanita 15-49 Papua, 8,49 tahun dan tertinggi pada tahun di Indonesia menurut SDKI 2017 Provinsi Yogyakarta, 11,67 tahun. Masih adalah 9,95 tahun, artinya seorang wanita ada 20 provinsi di Indonesia dengan ratarata-rata menyelesaikan sekolah hanya rata lama sekolah kurang dari rata-rata sampai kelas 1 SMA. Rata-rata lama nasional. sekolah terendah berada pada Provinsi 


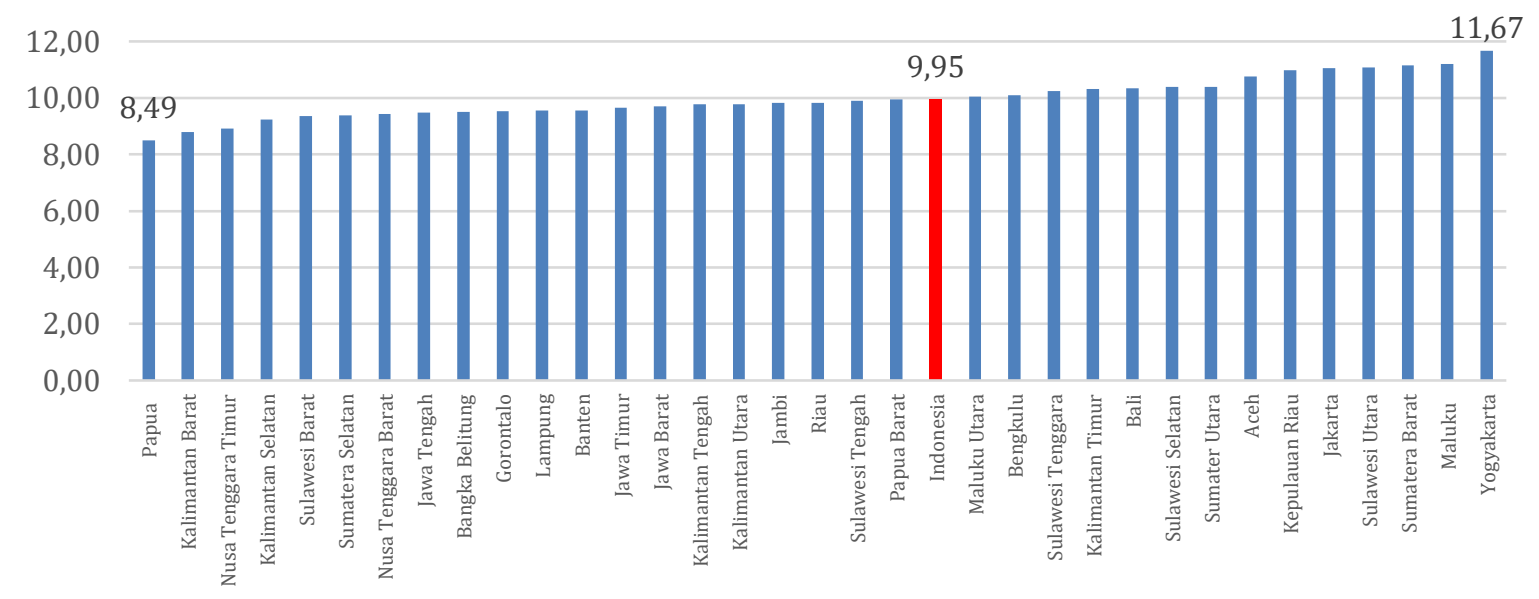

Gambar 5. Rata-rata Lama Sekolah menurut Provinsi, 2017 Sumber : SDKI 2017, diolah

\section{Hasil Analisis Cluster}

Pada penelitian ini, jumlah cluster telah ditentukan sebelumnya oleh peneliti. Penentuan jumlah cluster terbaik dilakukan dengan Metode Elbow. Untuk menentukan jumlah cluster terbaik, dilakukan percobaan dengan menggunakan scenario dua sampai dengan delapan cluster. Metode Elbow menunjukkan bahwa jumlah cluster terbaik adalah empat cluster. Hasil Metode Elbow dapat dilihat pada gambar 6 berikut:

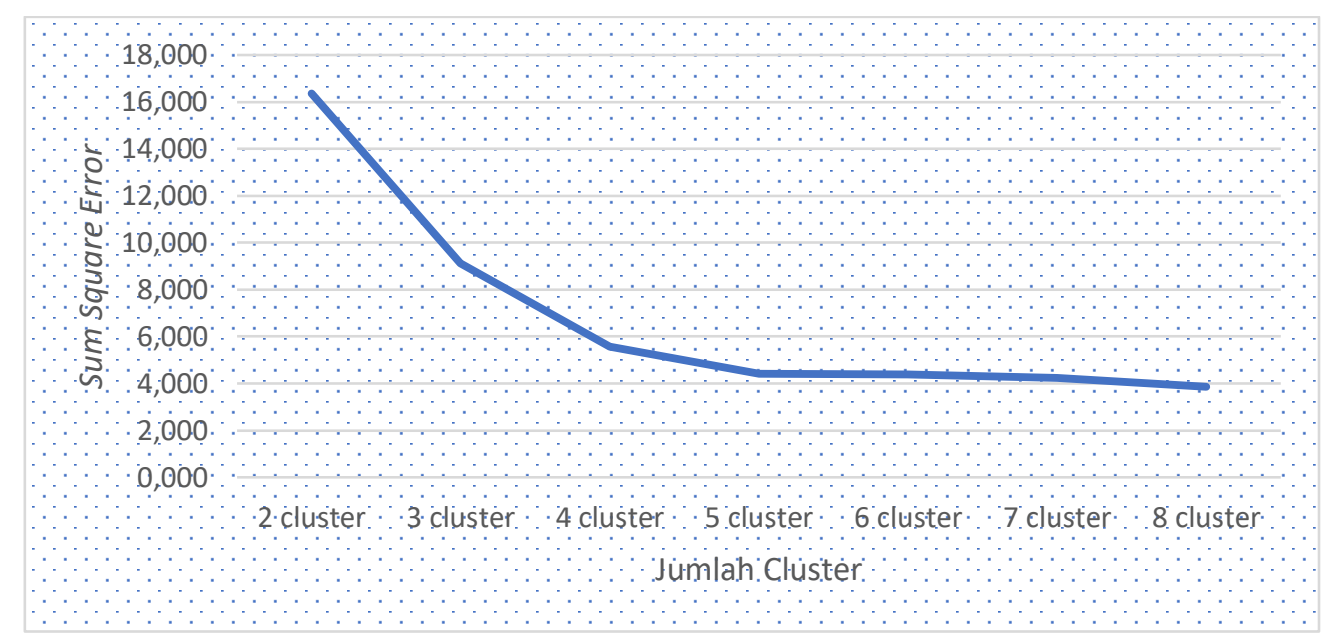

Gambar 6. Sum Square Error (SSE) untuk cluster berjumlah 2 sampai 8 cluster Sumber: Olahan Penulis

Dapat dilihat pada gambar 6 bahwa nilai SSE berkurang secara tajam pada jumlah cluster 3 dan 4 . Kemudian, pada jumlah cluster lebih dari 4, nilai SSE tidak berkurang secara signifikan. Oleh karena itu, maka penelitian ini menggunaka jumlah cluster sebanyak 4 cluster.
Selanjutnya, karena nilai variabelvariabel pada penelitian ini berbeda-beda, maka perlu dilakukan standardisasi pada nilai masing-masing variabel tersebut. Nilai standard (Zscore) tersebut yang digunakan dalam analisis cluster. Hasil analisis cluster tersebut dapat dilihat pada tabel 1 berikut ini: 
Tabel 1.

Hasil Analisis Cluster

\begin{tabular}{lrrrr}
\hline \multicolumn{1}{c}{ Karakteristik Unmet Need } & Cluster 1 & Cluster 2 & Cluster 3 & Cluster 4 \\
\hline Zscore Unmet Need & 1,62 & $-0,31$ & 0,41 & $-0,54$ \\
Zscore TPAK Perempuan & 1,42 & 0,57 & $-0,67$ & $-0,15$ \\
Zscore Median Usia Kawin Pertama & $-0,03$ & 1,78 & 0,18 & $-0,65$ \\
Zscore Jumlah Anak Masih Hidup & 1,49 & $-1,34$ & 0,50 & $-0,23$ \\
Zscore Rata-rata Lama Sekolah & $-0,85$ & 1,43 & 0,62 & $-0,58$ \\
Zscore Anggota Cluster & 4 & 5 & 9 & 16 \\
\hline
\end{tabular}

Sumber : Olahan Penulis

Pada tabel 1 dapat dilihat bahwa Zscore bernilai positif dan negatif. Apabila Zscore positif, artinya nilai rata-rata cluster tersebut lebih besar daripada nilai rata-rata populasi. Dapat dilihat bahwa pada cluster 1, nilai unmet need, TPAK perempuan, dan jumlah anak masih hidup bernilai positif dan median usia kawin pertama serta ratarata lama sekolah bernilai negatif. Artinya, cluster 1 terdiri dari provinsi-provinsi dengan tingkat unmet need, TPAK perempuan, dan jumlah anak masih hidup yang besar, dan median usia kawin pertama serta rata-rata lama sekolah rendah. Selanjutnya, cluster 2 terdiri dari provinsi- provinsi dengan unmet need yang rendah, jumlah anak masih hidup sedikit, TPAK perempuan, median usia kawin pertama, dan rata-rata lama sekolah yang tinggi.

Cluster 3 terdiri dari provinsi dengan TPAK perempuan rendah, dan mempunyai unmet need, median usia kawin pertama, jumlah anak masih hidup, dan rata-rata lama sekolah yang tinggi. Cluster 4 terdiri dari provinsi-provinsi dengan unmet need, TPAK perempuan, median usia kawin pertama, jumlah anak masih hidup, dan rata-rata lama sekolah rendah. Pengelompokan provinsi-provinsi tersebut dapat dilihat pada tabel 2 berikut ini:

Tabel 2.

Pengelompokan Provinsi Berdasarkan Analisis Cluster

\begin{tabular}{cl}
\hline Cluster & \multicolumn{1}{c}{ Provinsi } \\
\hline Cluster 1 & Nusa Tenggara Timur, Maluku Utara, Papua Barat, Papua \\
Cluster 2 & Sumatera Barat, Kepulauan Riau, Jakarta, Yogyakarta, Bali \\
Cluster 3 & $\begin{array}{l}\text { Aceh, Sumatera Utara, Riau, Kalimantan Timur, Kalimantan Utara, } \\
\text { Sulawesi Utara, Sulawesi Selatan, Sulawesi Tenggara, Maluku } \\
\text { Jambi, Sumatera Selatan, Bengkulu, Lampung, Bangka Belitung, Jawa } \\
\text { Barat, Jawa Tengah, Jawa Timur, Banten, Nusa Tenggara Barat, } \\
\text { Kalimantan Barat, Kalimantan Tengah, Kalimantan Selatan, Gorontalo, } \\
\text { Sulawesi Barat }\end{array}$ \\
\hline
\end{tabular}

Sumber: Olahan Penulis 
Dari hasil pengelompokan provinsi berdasarkan analisis cluster, dapat dilihat bahwa provinsi-provinsi yang berdekatan memiliki kecenderungan untuk berada pada cluster yang sama. Ronald Freedman (1975) dalam Adioetomo \& Samosir (2010) mengembangkan suatu model sosiologi terhadap fertilitas. Model tersebut menunjukkan bahwa ada hubungan yang kuat antara lingkungan dan struktur sosial ekonomi. Struktur sosial ekonomi saling berpengaruh dengan norma mengenai besarnya keluarga yang berlaku di suatu wilayah dan pada akhirnya memengaruhi fertilitas melalui variabel antara, salah satunya adalah pemakaian kontrasepsi. Hal ini dapat menjelaskan mengapa wilayahwilayah yang berdekatan cenderung mengelompok pada cluster yang sama, karena norma yang berlaku pada wilayah tersebut cenderung sama.

Selanjutnya, untuk melihat perbedaan variabel pada cluster yang terbentuk, dapat dilihat pada tabel anova yang disajikan pada tabel 3 berikut ini:

Tabel 3.

Tabel Anova Hasil SPSS

\begin{tabular}{lcccccc}
\hline & Cluster & \multicolumn{2}{c}{ Error } & F & Sig. \\
& Mean Square & df & Mean Square & df & & \\
\hline Zscore unmet need & 5.715 & 3 & 0.529 & 30 & 10.812 & 0.000 \\
Zscore TPAK Perempuan & 4.705 & 3 & 0.630 & 30 & 7.474 & 0.001 \\
$\begin{array}{l}\text { Zscore median usia kawin } \\
\text { pertama }\end{array}$ & 7.666 & 3 & 0.333 & 30 & 22.996 & 0.000 \\
Zscore jumlah anak masih hidup & 7.017 & 3 & 0.398 & 30 & 17.617 & 0.000 \\
Zscore rata-rata lama sekolah & 7.365 & 3 & 0.364 & 30 & 20.259 & 0.000 \\
\hline
\end{tabular}

Sumber: Olahan Penulis

Pada tabel 3, dilihat dari nilai yang bervariasi dalam hal sifat dan signifikansinya, maka dapat dikatakan karakteristiknya. Clustering provinsi bahwa semua variabel tersebut signifikan berdasarkan tingkat unmet need $\mathrm{KB}$ pada $\alpha=0,05$. Artinya bahwa memang ada bertujuan untuk membuka ruang diskusi perbedaan dari variabel-variabel tersebut antar cluster. Dilihat dari nilai $\mathrm{F}$, nilai $\mathrm{F}$ yang tertinggi adalah pada variabel median usia kawin pertama. Artinya, nilai median usia kawin pertama antar cluster memiliki perbedaan yang plaing tinggi dibandingkan variabel-variabel lainnya.

\section{SIMPULAN}

Dimensi kewilayahan harus menjadi perhatian dalam menganalisis unmet need KB di Indonesia. Penduduk sebagai pelaku bagi permasalahan kesenjangan unmet need $\mathrm{KB}$ antar provinsi di Indonesia.

\section{Pengelompokan provinsi-provinsi} berdasarkan tingkat unmet need $\mathrm{KB}$ dan faktor-faktor yang memengaruhinya menghasilkan empat kelompok. Provinsiprovinsi yang berdekatan cenderung mengelompok pada cluster yang sama, diduga karena adanya norma sosial yang bersifat mirip pada wilayah-wilayah yang berdekatan. 


\section{DAFTAR PUSTAKA}

Adioetomo, S. M., \& Samosir, O. B. (2010). Dasar-Dasar Demografi. Salemba Empat.

Ali, A. A. A., \& Okud, A. (2013). Factors affecting unmet need for family planning in Eastern Sudan. BMC Public Health, 13, 102. https://doi.org/10.1186/1471-2458-13102

Anggraeni, A. (2016). Pemodelan Faktor-Faktor yang Mempengaruhi Unmet Need KB di Provinsi Jawa Timur dengan Regresi Nonparametrik Spline. Institut Teknologi Sepuluh Nopember.

Bappenas. (2015). Rencana Pembangunan Jangka Menengah Nasional 2015-2019. In Rencana Pembangunan Jangka Menengah Nasional 2015-2019. https://doi.org/10.1017/CBO9781107415324.004

Clark, C. J., Spencer, R. A., Khalaf, I. A., Gilbert, L., El-Bassel, N., Silverman, J. G., \& Raj, A. (2017). The influence of family violence and child marriage on unmet need for family planning in Jordan. Journal of Family Planning and Reproductive Health Care, 43(2), 105-112. https://doi.org/10.1136/jfprhc-2014-101122

Hailemariam, A., \& Haddis, F. (2011). Factors Affecting Unmet Need for Family Planning In Southern Nations, Nationalities and Peoples Region, Ethiopia. Ethiopian Journal of Health Sciences, 21(2), 77-89. https://doi.org/10.4314/ejhs.v21i2.69048

Imasiku, E. N. S., Odimegwu, C. O., Adedini, S. A., \& Ononokpono, D. N. (2014). Variations in unmet need for contraception in zambia: Does ethnicity play a role? Journal of Biosocial Science, 46(3), 294-315. https://doi.org/10.1017/S0021932013000357

Jidar, M. (2018). Determinan Kejadian Unmet Need KB Pada Pasangan Usia Subur (PUS) di Sulawesi Selatan (Perbandingan Antara Wilayah Urban dan Rural). Universitas Hasanuddin.

Nindya, T. (2011). Disparitas Unmet Need KB Antar Kabupaten/Kota di Propinsi Jawa Timur berdasarkan Karakteristik Sosio-Demografi dan Alasan Unmet Need (Analisis Lanjut Data Mini Survey 2010). Universitas Airlangga.

Novianto, A., Emilia, O., \& Dasuki, D. (2017). Unmet need KB pada pasangan usia subur di kecamatan Kraton Yogyakarta. Berita KEdokteran Masyarakat, 33-36.

Nzokirishaka, A., \& Itua, I. (2018). Determinants of unmet need for family planning among married women of reproductive age in Burundi: a cross-sectional study. Contraception and Reproductive Medicine, 3(1), 1-13. https://doi.org/10.1186/s40834-018-0062-0

Paramita, D. F., \& Baroya, N. (2017). Hubungan antara Otonomi Perempuan dan Persepsi terhadap Pelayanan Konseling KB dengan Unmet Need KB pada Pasangan Usia Subur di Kecamatan Sumberjambe Kabupaten Jember ( Association between Women ' s Autonomy and Perception of Counseling Services FP Spouse. E-Jurnal Pustaka Ksehatan, 5(2), 214-222.

Putro, D., \& Listyaningsih, U. (2017). Unmet Need Keluarga Berencana di Daerah Perkotaan dan Perdesaan di Provinsi Daerah Istimewa Yogyakarta. Jurnal Bumi Indonesia, 6(4). 
Withers, M., Kano, M., \& Pinatih, G. N. I. (2010). Desire for more children, contraceptive use and unmet need for family planning in a remote area of Bali, Indonesia. Journal of Biosocial Science, 42(4), 549-562. https://doi.org/10.1017/S0021932010000052

Wulifan, J. K., Brenner, S., Jahn, A., \& De Allegri, M. (2016). A scoping review on determinants of unmet need for family planning among women of reproductive age in low and middle income countries. BMC Women's Health, 16(1). https://doi.org/10.1186/s12905-015-0281-3 